Pawel Marek Woroniecki

Uniwersytet Jagielloński

\title{
Ulgi podatkowe jako czynnik wspierający podmioty gospodarcze w okresie dekoniunktury rynkowej
}

\section{Tax reliefs as an instrument of supporting economic agents during a market recession}

\begin{abstract}
Streszczenie
Artykuł prezentuje wybrane ulgi podatkowe skierowane w szczególności do przedsiębiorców. Polski ustawodawca wprowadził wiele ulg podatkowych i niektóre z nich mogą być szczególnie pomocne w okresie dekoniunktury rynkowej.

W pierwszej kolejności w artykule zostało wyjaśnione pojęcie ulga podatkowa. Ponadto artykuł prezentuje niektóre regulacje zawarte w wybranych aktach prawnych. W szczególności opisuje on kluczowe rozwiązania prawne związane z ulgami podatkowymi, które wynikają z Ustawy z dnia 29 sierpnia 1997 r. Ordynacja podatkowa. W artykule wspomina się także o niektórych rozwiązaniach prawnych zawartych zwłaszcza w Ustawie z dnia 15 lutego 1992 r. o podatku dochodowym od osób prawnych oraz w Ustawie z dnia 20 października 1994 r. o specjalnych strefach ekonomicznych. W tym kontekście należy podkreślić, że podmioty gospodarcze mogą korzystać z ulg podatkowych tylko pod pewnymi warunkami wprowadzonymi przez polskiego ustawodawcę. $Z$ tego też powodu bardzo ważne jest wskazanie prawnych przesłanek ich wykorzystywania. Kwestie te zostały bliżej przeanalizowane $\mathrm{w}$ artykule.
\end{abstract}

\begin{abstract}
The paper presents selected tax reliefs, designed particularly for entrepreneurs. The Polish legislature has introduced a great many tax reliefs, and some of them can be particularly helpful during market recession.

Firstly, the meaning of the term 'tax relief' is explained in the article. Furthermore, the paper presents certain legal regulations, found in selected legal acts. In particular, it describes significant legal solutions connected with tax reliefs, which result from the Tax Ordinance Act of 29th August 1997. In addition, the article touches upon legal solutions, introduced especially in the Corporate Income Tax Act of 15th February 1992 and in the Special Economic Zones Act of 20th October 1994. In this context, it must be emphasized that economic agents may enjoy tax reliefs only under certain conditions, introduced by the Polish legislature. That is why it is very important to designate the legal prerequisites for taking advantage of them. These matters are closely analysed in the paper.
\end{abstract}

Słowa kluczowe: dekoniunktura rynkowa; podmioty gospodarcze; ulgi podatkowe Key words: market recession; economic agents; tax reliefs

\section{Wprowadzenie}

Bez wątpienia okres dekoniunktury rynkowej uwydatnia znaczenie różnego rodzaju ulg podatkowych. Celem niniejszego opracowania jest przedstawienie w sposób syntetyczny wybranych 
ulg podatkowych, które są dostępne dla podmiotów gospodarczych. W tym kontekście warto podkreślić, że rozwój zarówno pojedynczych firm, jak i gospodarek poszczególnych krajów uzależniony jest w dużej mierze od obowiązującego systemu podatkowego (Wisła, 2004: 191).

$\mathrm{Na}$ wstępie niezbędne jest wskazanie, czym - w aspekcie prawnym - są ulgi podatkowe. W literaturze przedmiotu wskazuje się, że ulgi takie „polegają na ograniczeniu wielkości obciążenia podatkowego - w określonych przypadkach - w stosunku do obciążenia przyjętego za przeciętne w danym podatku" (Brzeziński, 2008: 63). Wśród ulg podatkowych wyodrębnia się m.in. ulgi systemowe, czyli takie, które zostały przez ustawodawcę włączone do unormowań regulujących poszczególne podatki (Brzeziński, 2008: 63; Mastalski, 2011: 47).

Ponadto, w ogólnych przepisach regulujących zobowiązania podatkowe jest mowa o traktowaniu podatników w sposób ulgowy (Brzeziński, 2008: 63). Trzeba tutaj wspomnieć w szczególności o rozdziale 7a Ustawy z dnia 29 sierpnia $1997 \mathrm{r}$. Ordynacja podatkowa (tekst jednolity: Dz.U. z dnia 3 lipca 2012 r., poz. 749 z późniejszymi zmianami), zatytułowanym Ulgi w splacie zobowiąań podatkowych, który jest zamieszczony w dziale III tej ustawy noszącym tytuł Zobowiazania podatkowe. W rozdziale tym ustawodawca zawarł - podobnie zresztą jak w artykułach 22 i 48 Ordynacji podatkowej - regulacje będące ulgami uznaniowymi, które opierają się na uznaniu administracyjnym (Etel, 2009: 232, 235, 310-311, 371; zob. też: Gruszczyński, 2011: 211 oraz Dauter, 2011: 308-310, 381-383, 385). Ulgi uznaniowe, jak również zwolnienia uznaniowe, odwołują się do określonych sytuacji faktycznych, których ustalenie następuje w ramach postępowania podatkowego. Chodzi w szczególności o to, że przepisy prawne mogą wymieniać pewne stany faktyczne - przy użyciu mało precyzyjnych sformułowań wskazujących np. na sytuację majątkową podatnika - które muszą stać się udziałem podatnika, aby organ podatkowy miał prawo zastosować w stosunku do niego daną ulgę lub zwolnienie (Mastalski, 2011: 47-48).

Bardzo ważny podział ulg podatkowych (a także zwolnień podatkowych) nawiązuje do celu, jaki został im przypisany przez ustawodawcę. W tym zakresie wyodrębnia się ulgi/zwolnienia gospodarcze, społeczne i inne (Nykiel, 2002: 191). Te pierwsze mają za zadanie przynieść odpowiednie zmiany w systemie gospodarczym. Może tutaj chodzić m.in. o polepszenie kondycji ekonomicznej podmiotów gospodarczych, wzrost eksportu, wzrost oszczędności, generowanie inwestycji. Z kolei ulgi/zwolnienia społeczne mają pomóc w osiągnięciu pewnych celów społecznych (Nykiel, 2002: 191-192).

Oprócz teoretycznych objaśnień terminu ulga podatkowa w polskim systemie prawnym występuje także normatywne ujęcie tego terminu. Zamieszczone jest ono w art. 3 pkt 6) Ordynacji podatkowej, który stanowi, że ilekroć mówi się w tej ustawie na temat ulg podatkowych, pojęcie to należy utożsamiać z określonymi w przepisach podatkowych zwolnieniami, odliczeniami, obniżkami albo zmniejszeniami, które po zastosowaniu będą skutkowały tym, że podstawa opodatkowania lub też wysokość samego podatku ulegną zmniejszeniu (spod pojęcia ulga podatkowa powyższy przepis wyłącza jednak operację polegającą na obniżeniu - o kwotę podatku naliczonego - kwoty podatku należnego, w ujęciu regulacji dotyczących podatku od towarów i usług, oraz inne odliczenia, które są elementem konstrukcyjnym tego podatku). Termin ulga podatkowa, występujący w tytule niniejszego opracowania, obejmuje swoim zakresem znaczeniowym również treść tego pojęcia wynikającą z art. 3 pkt 6) Ordynacji podatkowej.

\section{Dekoniunktura rynkowa a zaawansowane rozwiązania technologiczne (ujęcie podatkowe)} W okresie kryzysu gospodarczego przedsiębiorcy starają się na różne sposoby przetrwać na rynku. Niewątpliwie wprowadzenie zaawansowanych rozwiązań technologicznych jest czynnikiem, który może w tym bardzo pomóc. Tego rodzaju działania mają swoje konsekwencje 
podatkowe. Należy tutaj wspomnieć przede wszystkim o rozwiązaniach wynikających z Ustawy z dnia 15 lutego 1992 r. o podatku dochodowym od osób prawnych (tekst jednolity: Dz.U. z 2011 r. nr 74, poz. 397 z późniejszymi zmianami). W myśl art. 18b ust. 1 tej ustawy, wydatki, które podatnik poniósł na nabycie nowych technologii, podlegają odliczeniu od podstawy opodatkowania, która została ustalona w myśl art. 18 ustawy o podatku dochodowym od osób prawnych. Trzeba w tym miejscu wyjaśnić, co ustawodawca rozumie pod pojęciem nowe technologie. Otóż, zgodnie z ust. 2 wspomnianego wyżej art. 18b, tego rodzaju technologie to - w rozumieniu art. 18b ust. 1 - przyjmująca formę wartości niematerialnych i prawnych wiedza technologiczna (chodzi tutaj zwłaszcza o rezultaty badań i prac rozwojowych), dzięki której możliwe jest tworzenie nowych wyrobów lub usług (lub też udoskonalanie już istniejących), i której okres stosowania na świecie nie przekracza ostatnich pięciu lat, co musi znaleźć potwierdzenie w opinii wydanej przez jednostkę naukową (jednostka ta musi być niezależna od podatnika) w rozumieniu Ustawy z dnia 30 kwietnia 2010 r. o zasadach finansowania nauki (Dz.U. z 2010 r. nr 96, poz. 615 z późniejszymi zmianami). Jednostki naukowe to, w myśl art. 2 pkt 9 lit. a)-f) ustawy o zasadach finansowania nauki, podmioty zajmujące się w sposób ciągły prowadzeniem badań naukowych lub prac rozwojowych, które jednocześnie można zakwalifikować do jednej z określonych w tym przepisie form organizacyjnych, to znaczy do podstawowych jednostek organizacyjnych uczelni, jednostek naukowych Polskiej Akademii Nauk, instytutów badawczych, Polskiej Akademii Umiejętności, funkcjonujących na obszarze Polski instytutów naukowych o charakterze międzynarodowym, które zostały powołane na podstawie odrębnych przepisów, jak również do innych jednostek organizacyjnych spełniających ustawowo określone warunki.

Znaczenie powyższych regulacji podatkowych, dotyczących nowych technologii, wzmacnia fakt, że - jak podkreśla się w literaturze przedmiotu - polską gospodarkę cechuje stosunkowo niski stopień innowacyjności (Ciborowski, 2005: 314). Jednocześnie trwały rozwój państwa opiera się na innowacyjności samych obywateli, jak i całej gospodarki oraz administracji publicznej (Frąckowiak, 1999: 11).

Wracając do unormowań zawartych w ustawie o podatku dochodowym od osób prawnych, należy zwrócić uwagę na ust. 2a (zawarty w art. 18b tej ustawy), który to przepis precyzuje, że pod pojęciem nabywanie nowej technologii należy rozumieć nie tylko nabycie praw do wspomnianej wyżej wiedzy technologicznej przez zawarcie umowy dotyczącej ich przeniesienia, ale także korzystanie $\mathrm{z}$ praw do takiej wiedzy. Jeżeli chodzi o ustalenie wielkości odliczenia, to - zgodnie $\mathrm{z}$ art. $18 \mathrm{~b}$ ust. 4 analizowanej ustawy - podstawą tego ustalenia jest kwota zrealizowanych przez podatnika wydatków na nabycie wspomnianej technologii, które zostały uwzględnione „w wartości początkowej, w części, w jakiej została zapłacona podmiotowi uprawnionemu w roku podatkowym, w którym nową technologię wprowadzono do ewidencji środków trwałych oraz wartości niematerialnych i prawnych lub w roku następującym po tym roku, oraz w której nie została zwrócona podatnikowi w jakiejkolwiek formie". Gdy w roku, który poprzedza rok wprowadzenia nowej technologii do wspomnianej wyżej ewidencji, podatnik wpłacił zadatki lub przedpłaty na konto wydatków służących nabyciu nowej technologii, wówczas ustawa o podatku dochodowym od osób prawnych przewiduje, że mają one zostać uznane za poniesione w tym roku, w którym nowa technologia została wprowadzona do ewidencji środków trwałych oraz wartości niematerialnych i prawnych (art. 18b ust. 5 tej ustawy).

W pewnych okolicznościach ustawa o podatku dochodowym od osób prawnych odbiera podatnikowi prawo do dokonywania odliczeń, mających związek z nabywaniem nowej technologii. Sytuacja taka ma miejsce, w myśl art. 18 b ust. 8 pkt 1), 2) i 3) tej ustawy, gdy podatnik umieścił nową technologię w wymienionej wyżej ewidencji i w okresie krótszym niż trzy lata 
podatkowe (początkiem biegu tego terminu jest koniec roku podatkowego, w ramach którego nowa technologia została wprowadzona do ewidencji): inne podmioty uzyskały od niego (w dowolnej formie lub części) prawa do takiej technologii (jednakże odliczenia mogą być dokonywane w przypadku, gdy przeniesienie prawa jest następstwem przeobrażeń w zakresie formy prawnej oraz działań polegających na łączeniu lub podziale dotychczasowych przedsiębiorców - realizowanych w oparciu o regulacje zawarte w Kodeksie spótek handlowych) albo nastąpi ogłoszenie upadłości podatnika obejmującej likwidację majątku (lub też postawiony on będzie w stan likwidacji), albo zostaną mu zwrócone - w dowolnej formie - wydatki na nową technologię.

Podatnik nie ma natomiast prawa do odliczeń w przypadku, gdy była przez niego prowadzona działalność (ustawodawca precyzuje, że chodzi tutaj o prowadzenie działalności w roku podatkowym lub roku go poprzedzającym), w oparciu o zezwolenie, na obszarze objętym specjalną strefą ekonomiczną (art. 18b ust. 3 ustawy o podatku dochodowym od osób prawnych) ${ }^{1}$.

Należy w tym miejscu podkreślić, iż funkcjonowanie w ramach wspomnianych wyżej specjalnych stref ekonomicznych również posiada swoje konsekwencje podatkowe, które nie są bez znaczenia dla podatników funkcjonujących w okresie dekoniunktury rynkowej.

\section{Specjalne strefy ekonomiczne}

Podstawowym aktem prawnym dotyczącym funkcjonowania specjalnych stref ekonomicznych w Polsce jest Ustawa z dnia 20 października 1994 r. o specjalnych strefach ekonomicznych (tekst jednolity: Dz.U. z 2007 r. nr 42, poz. 274 z późniejszymi zmianami). Specjalna strefa ekonomiczna to - w myśl art. 2 wymienionej wyżej ustawy - ,wyodrębniona zgodnie z przepisami ustawy, niezamieszkała część terytorium Rzeczypospolitej Polskiej, na której terenie może być prowadzona działalność gospodarcza na zasadach określonych ustawą".

Zgodnie z art. 3 pkt 1), 2), 3), 4), 5), 6), 7) ustawy o specjalnych strefach ekonomicznych, utworzenie strefy może nastąpić celem zdynamizowania rozwoju ekonomicznego określonego obszaru Polski, zwłaszcza przez rozwinięcie wybranych gałęzi działalności gospodarczej, rozwinięcie nowych koncepcji z zakresu techniki i technologii oraz ich zastosowanie w gospodarce, rozwinięcie działalności eksportowej, podniesienie poziomu konkurencyjności produkowanych wyrobów oraz dostarczanych usług, kreowanie dodatkowych miejsc pracy oraz zagospodarowywanie występującego mienia przemysłowego, istniejącej infrastruktury gospodarczej czy zasobów naturalnych, które pozostają niewykorzystane (w przypadku zasobów naturalnych musi być przestrzegana zasada równowagi ekologicznej).

Osoby fizyczne lub prawne, które prowadzą działalność gospodarczą na terenie specjalnej strefy ekonomicznej w granicach zezwolenia, są w dogodnej sytuacji podatkowej, bowiem dochody z takiej działalności podlegają zwolnieniu od podatku dochodowego, przy czym zasady takiego zwolnienia regulują odpowiednie przepisy podatkowe, tj. o podatku dochodowym od osób fizycznych lub prawnych (art. 12 ustawy o specjalnych strefach ekonomicznych).

Jeżeli chodzi o wspomnianą wyżej ustawę o podatku dochodowym od osób prawnych, to jej art. 17 ust. 1 pkt 34) stanowi, że od podatku wolne są dochody (z uwzględnieniem jednak postanowień zawartych w art. 17 ust. 4-6 ustawy o podatku dochodowym od osób prawnych), które przynosi działalność gospodarcza realizowana na obszarze specjalnej strefy ekonomicznej w oparciu o zezwolenie wskazane w art. 16 ust. 1 ustawy o specjalnych strefach ekono-

\footnotetext{
${ }^{1} \mathrm{Na}$ temat odliczeń od podstawy opodatkowania wydatków zrealizowanych przez podatnika z tytułu nabycia nowych technologii zob. też art. $18 \mathrm{~b}$ ust. 6, 7, 9, 10 i 11 ustawy o podatku dochodowym od osób prawnych.
} 
micznych, z tym że zakazane jest, aby wysokość pomocy publicznej, która jest udzielana w postaci takiego zwolnienia, była wyższa od wielkości tego rodzaju pomocy dla przedsiębiorcy, dozwolonej dla terenów spełniających warunki dla otrzymania pomocy w najwyższej wysokości, w myśl odrębnych regulacji. Podatnikowi zwolnienie to przysługuje, jak stanowi art. 17 ust. 4 ustawy o podatku dochodowym od osób prawnych, jedynie z tytułu dochodów, jakie przynosi mu działalność prowadzona na obszarze specjalnej strefy ekonomicznej, przy czym ten sam art. 17 w ust. 5 stanowi, że konsekwencją cofnięcia wymienionego wyżej zezwolenia jest utrata przez podatnika prawa do zwolnienia oraz obowiązek uiszczenia podatku za pełny okres, w którym z takiego zwolnienia podatkowego korzystał (obowiązki podatnika powstałe wskutek cofnięcia zezwolenia szczegółowo reguluje ust. 6 zawarty w omawianym art. 17 ustawy o podatku dochodowym od osób prawnych). Analogiczne regulacje do przedstawionych wyżej unormowań zawartych w ustawie o podatku dochodowym od osób prawnych występują w art. 21 ust. 1 pkt 63a) i ust. 5a, 5b i 5c Ustawy z dnia 26 lipca 1991 r. o podatku dochodowym od osób fizycznych (tekst jednolity: Dz.U. z dnia 3 kwietnia 2012 r., poz. 361 z późniejszymi zmianami), która to ustawa reguluje, zgodnie z jej art. 1, opodatkowanie tym podatkiem dochodów osób fizycznych.

Ze wspomnianego wyżej art. 16 ust. 1 ustawy o specjalnych strefach ekonomicznych wynika, że do korzystania z pomocy publicznej, która jest udzielana w myśl tej ustawy, wymagane jest zezwolenie na prowadzenie działalności gospodarczej na obszarze określonej strefy dające uprawnienie do korzystania z takiej pomocy. Nie można przy tym zapominać, że - w myśl art. 19a ustawy o specjalnych strefach ekonomicznych - tego rodzaju działalność gospodarcza przedsiębiorcy podlega kontroli stosownie do regulacji zawartych w rozdziale 5 Ustawy z dnia 2 lipca 2004 r. o swobodzie działalności gospodarczej (tekst jednolity: Dz.U. z 2010 r. nr 220, poz. 1447 z późniejszymi zmianami).

\section{Ulgi przewidziane w Ordynacji podatkowej (wybrane kwestie)}

Jak już wspomniano, bardzo istotne regulacje dotyczące ulg podatkowych zostały przez ustawodawcę przewidziane w rozdziale 7a Ordynacji podatkowej, który nosi tytuł Ulgi w spłacie zobowiazań podatkowych (art. 67a-67e). Rozdział 7a umiejscowiony jest w dziale III tej ustawy.

Artykuł 67a § 1 pkt 1), 2) i 3) Ordynacji podatkowej przewiduje, że na wniosek złożony przez podatnika, organ podatkowy, z zastrzeżeniem postanowień zawartych w art. 67b Ordynacji podatkowej, może zadecydować o odroczeniu terminu zapłaty podatku lub o rozłożeniu na raty jego zapłaty, o odroczeniu lub rozbiciu na raty zapłaty zaległości podatkowej łącznie z odsetkami wynikającymi ze zwłoki lub odsetek wskazanych w decyzji wymienionej w art. 53a Ordynacji podatkowej, a także może zadecydować - w odniesieniu do zaległości podatkowych, odsetek za zwłokę lub opłaty prolongacyjnej - o ich umorzeniu w całości lub w części, przy czym wszelkie wspomniane wyżej działania organ podatkowy może przedsięwziąć jedynie wówczas, gdy jest to uzasadnione z uwagi na ważny interes podatnika lub interes publiczny. Przytoczone powyżej rozwiązania prawne prezentuje w sposób syntetyczny tabela 1 .

Warto w tym miejscu zaznaczyć, że jako nadpłatę należy potraktować sytuację, w której dany podmiot płaci zaległość podatkową objętą umorzeniem lub odsetki za zwłokę (opłatę prolongacyjną) nim objęte (Dauter, 2011: 378). Wzmiankowany art. 67a Ordynacji podatkowej precyzuje $\mathrm{w} \S 2$, że wskutek umorzenia zaległości podatkowej następuje też umorzenie odsetek za zwłokę, przy czym umorzeniu podlega całość odsetek lub też są one umarzane w części, w jakiej umorzono samą zaległość podatkową.

Przedstawione regulacje wymagają pewnych dodatkowych wyjaśnień. W szczególności słusznie podkreśla się w literaturze przedmiotu, że zawartość składanego przez podatnika 
Tab. 1. Wybrane ulgi przewidziane w Ordynacji podatkowej

\begin{tabular}{|c|c|}
\hline Ulga & Podstawa prawna \\
\hline Odroczenie terminu płatności podatku & \multirow{2}{*}{ art. 67a § 1 pkt 1) Ordynacji podatkowej } \\
\hline Rozłożenie zapłaty podatku na raty & \\
\hline $\begin{array}{l}\text { Odroczenie lub rozłożenie na raty zapłaty zaległości podat- } \\
\text { kowej wraz z odsetkami za zwłokę lub odsetek określonych } \\
\text { w decyzji wskazanej w art. 53a Ordynacji podatkowej }\end{array}$ & art. 67a $\S 1$ pkt 2) Ordynacji podatkowej \\
\hline Umorzenie w całości lub w części zaległości podatkowych & \multirow{3}{*}{ art. 67a § 1 pkt 3) Ordynacji podatkowej } \\
\hline Umorzenie w całości lub w części odsetek za zwłokę & \\
\hline Umorzenie w całości lub w części opłaty prolongacyjnej & \\
\hline
\end{tabular}

Źródło: opracowanie na podstawie art. 67a § 1 Ustawy z dnia 29 sierpnia 1997 r. Ordynacja podatkowa (tekst jednolity: Dz.U. z dnia 3 lipca 2012 r., poz. 749 z późniejszymi zmianami).

wniosku o udzielenie ulgi w spłacie zobowiązań podatkowych, jest dla organu podatkowego wiążąca, a zatem niedopuszczalna jest np. sytuacja polegająca na tym, że organ odracza termin płatności podatku, choć wnioskodawca zwracał się o rozłożenie jego zapłaty na raty (Etel, 2009: 372).

Wymieniony wyżej art. 53a Ordynacji podatkowej wyznacza, w $\S 1$, sposób postępowania organu podatkowego w przypadku stwierdzenia przez niego (w ramach postępowania podatkowego po upływie roku podatkowego lub ewentualnie jakiegoś innego okresu rozliczeniowego), że podatnik nie złożył deklaracji chociaż był do tego zobowiązany, kwota zaliczek odbiega od tej która została ujęta w deklaracji lub nie doszło do zapłaty zaliczek w całości lub w części. Wówczas, zgodnie z dyspozycją tegoż art. 53a § 1, „organ ten wydaje decyzję, w której określa wysokość odsetek za zwłokę na dzień złożenia zeznania podatkowego za rok podatkowy lub inny okres rozliczeniowy, a w przypadku niezłożenia zeznania w terminie odsetki na ostatni dzień terminu złożenia zeznania, przyjmując prawidłową wysokość zaliczek na podatek". Całość powyższych regulacji zawartych w rzeczonym art. 53a § 1 znajduje odpowiednie zastosowanie w odniesieniu do zaliczek na podatek od towarów i usług (stanowi o tym art. 53a § 2 Ordynacji podatkowej).

W przytoczonym art. 67a $\S 1$ Ordynacji podatkowej ustawodawca wspomina o ważnym interesie podatnika i interesie publicznym. W doktrynie prawa zwraca się uwagę, iż są to terminy niejednoznaczne (Etel, 2009: 232; Dauter, 2011: 309, 382), przy czym kluczowy „wpływ na sprecyzowanie tych pojęć ma orzecznictwo sądowe" (Etel, 2009: 232). Należy też odnotować, że w myśl art. 67c § 1 Ordynacji podatkowej, regulacje zawarte w jej art. 67a § 1 pkt 1) i pkt 2) (chodzi tutaj o odraczanie terminu zapłaty podatku lub o rozkładanie jego zapłaty na raty, jak również o odraczanie lub rozkładanie na raty zapłaty zaległości podatkowej łącznie z odsetkami powstałymi wskutek zwłoki lub o odsetki wskazane w decyzji określonej w art. 53a Ordynacji podatkowej) i art. 67b (zob. niżej) trzeba odpowiednio stosować do należności, które przypadają od płatników i inkasentów. Natomiast wyżej wymieniony art. 67a znajduje w całości odpowiednie zastosowanie (tak samo zresztą, jak i cały art. 67b) do należności, które przypadają od spadkobierców podatnika lub płatnika oraz osób trzecich (art. 67c § 2 Ordynacji podatkowej).

Trzeba również podkreślić, że - zgodnie z art. 49 § 1 Ordynacji podatkowej - na skutek wydania decyzji w oparciu o art. 67a $\S 1$ pkt 1) lub pkt 2) pojawia się nowy termin zapłaty, przy czym jest nim dzień, w którym należy, w myśl wspomnianej decyzji wydanej na podstawie 
art. $67 \mathrm{a} \S 1$ pkt 1) lub pkt 2), uiścić odroczony podatek lub zaległość podatkową włącznie z odsetkami za zwłokę albo uiścić poszczególne raty, na które rozłożono podatek lub zaległość podatkową włącznie z odsetkami za zwłokę. Jednocześnie, jak stanowi art. 49 § 2 Ordynacji podatkowej, nieuiszczenie przez podatnika, w terminie wynikającym z takiej decyzji, wymienionych wyżej należności (w przypadku rozłożenia świadczenia na raty wystarczy, że choćby jedna $\mathrm{z}$ rat nie zostanie zapłacona) skutkuje tym, że terminem zapłaty podatku lub zaległości podatkowej podlegającej odroczeniu lub rozłożeniu na raty staje się odpowiednio termin wynikający z art. $47 \S 1-3$ Ordynacji podatkowej. Powyższe regulacje zamieszczone w art. $49 \S 1$ i $\S 2$ znajdują odpowiednie zastosowanie do należności płatników lub inkasentów, które zostały rozłożone na raty (art. 49 § 3 Ordynacji podatkowej). Artykuł 49 zawarty jest w rozdziale 4 zatytułowanym Terminy płatności objętym działem III Ordynacji podatkowej. W rozdziale tym znajduje się też art. 48, który w $§ 1$ stanowi, że terminy określone przepisami prawa podatkowego mogą być przez organ podatkowy - na wniosek podatnika - odraczane w sytuacjach, gdy jest to uzasadnione ważnym interesem podatnika lub interesem publicznym (odroczenie takie nie znajduje jednak zastosowania do wszystkich terminów - wyliczenie wyjątków poprzez wskazanie odpowiednich artykułów Ordynacji podatkowej objętych tym wyłączeniem zawiera tenże art. $48 \S 1$ ). Jak stanowi art. 48 § 2 Ordynacji podatkowej, powyższe regulacje zawarte $\mathrm{w}$ art. $48 \S 1$ mają odpowiednie zastosowanie także do terminów odnoszących się do płatników lub inkasentów. Uważa się, że możliwość odraczania terminów, unormowana w art. 48 Ordynacji podatkowej, stanowi rodzaj ulgi w spłacie podatków (Etel, 2009: 310, 371).

\section{Podmioty przyznające ulgi}

Kolejna kwestia, której nie można pominąć, dotyczy określenia podmiotów uprawnionych do przyznawania ulg wymienionych w rozdziale 7a Ordynacji podatkowej. Otóż na mocy art. 67e Ordynacji podatkowej określenie właściwości rzeczowej organów podatkowych w zakresie udzielania ulg w spłacie zobowiązań podatkowych musi nastąpić w ramach rozporządzenia ministra właściwego do spraw finansów publicznych, który w tej kwestii musi uwzględnić takie czynniki, jak: wielkość kwoty stanowiącej przedmiot ulgi i terminy wpłat dotyczące podatku lub też zaległości podatkowej. Trzeba w tym miejscu odwołać się do postanowień Rozporzadzenia Ministra Finansów z dnia 22 sierpnia 2005 r. w sprawie właściwości organów podatkowych (Dz.U. z 2005 r. nr 165, poz. 1371 z późniejszymi zmianami), które to rozporządzenie (dalej: rozporządzenie MF z dnia 22 sierpnia 2005 r.) - jak wynika z jego treści - zostało wydane między innymi w oparciu o wspomniany wyżej art. 67e Ordynacji podatkowej. W rozporządzeniu tym zawarty jest rozdział 4 zatytułowany Właściwość rzeczowa organów podatkowych $w$ sprawach związanych ze stosowaniem ulg $w$ spłacie zobowiązań podatkowych, obejmujący tylko $\S 15$. Zgodnie z $\S 15$ ust. 1 pkt 1), 2), 3), 4) i 5) rozporządzenia MF z dnia 22 sierpnia 2005 r., organy podatkowe, do których kompetencji należy - w myśl odrębnych regulacji - ustalanie lub określanie zobowiązań wynikających z podatków, opłat i niepodatkowych należności budżetowych (wszystkie te świadczenia rozporządzenie określa pojęciem podatki) są również właściwe w sprawach polegających na: a) zwalnianiu podmiotów będących płatnikami z obowiązku poboru podatku lub poboru zaliczek na podatek, b) ograniczaniu poboru zaliczek na podatek, c) całościowym lub częściowym umarzaniu zaległości podatkowych, opłaty prolongacyjnej lub odsetek z tytułu zwłoki (w sprawach wymienionych w powyższych punktach a), b) i c) organy podatkowe są właściwe bez ograniczenia kwoty), d) odraczaniu terminu zapłaty oraz rozkładaniu zapłaty podatku na raty, e) odraczaniu oraz rozkładaniu na raty takich świadczeń, jak zapłata zaległości podatkowej łącznie z odsetkami z tytułu zwłoki lub odsetek wynikających z decyzji wskazanej w omówionym wyżej art. 53a Ordynacji 
podatkowej, przy czym w sprawach wymienionych w powyższych punktach d) i e) organy podatkowe są właściwe bez ograniczenia zarówno co do kwoty, jak i co do okresu spłaty (w kwestii właściwości rzeczowej organów podatkowych w innych sprawach objętych rozdziałem 4 - zob. $\S 15$ ust. 2 i 3 rozporządzenia MF z dnia 22 sierpnia 2005 r.).

\section{Szczególne rozwiązania prawne dotyczące ulg}

Z kolei art. 67b § 1 pkt 1), 2) i 3) Ordynacji podatkowej daje organowi podatkowemu możliwość udzielenia - na wniosek podatnika, który prowadzi działalność gospodarczą - ulg w spłacie zobowiązań podatkowych, wymienionych w art. 67a Ordynacji podatkowej, które: a) nie są pomocą publiczną, b) są pomocą de minimis ${ }^{2}$, c) są pomocą publiczną udzielaną na realizację określonych zamierzeń. Podkreśla się w literaturze przedmiotu, że nie zawsze jest pomocą publiczną ulga w spłacie podatków, którą uzyskuje podmiot prowadzący działalność gospodarczą, a organy podatkowe, które podejmują rozstrzygnięcia w kwestii tego rodzaju ulg, muszą w każdym przypadku badać, czy ewentualnie takiej ulgi nie należałoby uznać za pomoc publiczną (Etel, 2009: 382). Organ podatkowy musi zatem już na wstępie sprawdzić charakter wnioskowanej pomocy (Dauter, 2011: 390). Trzeba jednocześnie zwrócić uwagę na fakt, że pojęcie pomoc publiczna jest precyzowane przede wszystkim w przepisach unijnych (zob.: Dauter, 2011: 390 i nast. oraz Etel, 2009: 380 i nast.).

Przed przystąpieniem do bardziej szczegółowej analizy powyższych kwestii należy sprecyzować pojęcie działalność gospodarcza, do którego odwołuje się wspomniany wyżej art. 67b. Otóż art. 3 pkt 9) Ordynacji podatkowej precyzuje, że pod pojęciem działalność gospodarcza należy rozumieć wszelką działalność zarobkową w takim znaczeniu, o jakim mówią regulacje o swobodzie działalności, wliczając w to praktykowanie wolnego zawodu, jak również wszelką inną działalność zarobkową, która jest prowadzona we własnym imieniu i na rachunek własny lub cudzy (chodzi tutaj nawet o takie przypadki, gdy dana działalność nie została zakwalifikowana przez odrębne ustawy do działalności gospodarczej lub gdy takie ustawy nie zaliczają do grona przedsiębiorców osoby, która takową działalność prowadzi). Z kolei art. 2 ustawy o swobodzie działalności gospodarczej wskazuje, że działalność gospodarcza to ,zarobkowa działalność wytwórcza, budowlana, handlowa, usługowa oraz poszukiwanie, rozpoznawanie i wydobywanie kopalin ze złóż, a także działalność zawodowa, wykonywana w sposób zorganizowany i ciągły". Z pojęciem działalność gospodarcza skorelowane jest pojęcie przedsiębiorca. W myśl art. $4 \S 1$ ustawy o swobodzie działalności gospodarczej, przedsiębiorcami - w rozumieniu tej ustawy - są wykonujące we własnym imieniu taką działalność: 1) osoby (chodzi tutaj zarówno o osoby fizyczne, jak i prawne) i 2) jednostki organizacyjne bez osobowości prawnej (taka jednostka musi jednak posiadać zdolność prawną przyznaną przez odrębną ustawę). Jak stanowi natomiast art. 4 § 2 ustawy o swobodzie działalności gospodarczej, wspólnicy spółki cywilnej uważani są również - w zakresie prowadzonej przez te podmioty działalności gospodarczej - za przedsiębiorców.

Wracając do rozwiązań przyjętych w art. 67b Ordynacji podatkowej, trzeba zwrócić uwagę, że przepis ten, w $§ 1$ pkt 3) lit. a)-m), określa różne zamierzenia, których realizacji musi służyć udzielenie - stanowiących pomoc publiczną - ulg w spłacie zobowiązań podatkowych. Jednym z warunków dopuszczalności udzielenia tego rodzaju ulgi jest to, aby była ona związana $\mathrm{z}$ realizacją któregoś z tych przedsięwzięć (Etel, 2009: 389). Warto przy tym pamiętać, że zgodnie

\footnotetext{
${ }^{2} \mathrm{~W}$ odniesieniu do pomocy de minimis, art. 67b § $1 \mathrm{pkt}$ 2) Ordynacji podatkowej stanowi, że udzielanie ulg stanowiących taką pomoc następuje ,,w zakresie i na zasadach określonych w bezpośrednio obowiązujących aktach prawa wspólnotowego dotyczących pomocy w ramach zasady de minimis".
} 
z art. 67b $\S 1$ pkt 3 lit. m) Ordynacji podatkowej, organ podatkowy może przyznawać ulgi podatkowe będące pomocą publiczną udzielaną na inne zamierzenia wskazane przez Radę Ministrów na podstawie $\S 6$ zamieszczonego w omawianym art. $67 \mathrm{~b}$. W myśl tego przepisu (art. 67b § 6) Rada Ministrów jest uprawniona do określenia, w formie rozporządzenia, odmiennego niż wymienione w art. 67b § 1 pkt 3) lit. a)-1) Ordynacji podatkowej przeznaczenia pomocy w postaci przyznawanych ulg w spłacie zobowiązań podatkowych (chodzi o ulgi wskazane w art. 67a Ordynacji podatkowej), jak również do określenia szczegółowych warunków, na jakich tego rodzaju ulgi są przyznawane dla przeznaczeń wskazanych przez Radę Ministrów, włącznie z wymienieniem sytuacji, w których udzielane ulgi przyjmują postać pomocy indywidualnej, uwzględniając unijne unormowania dotyczące dopuszczalności i warunków udzielania przez państwo pomocy.

Ordynacja podatkowa wprowadza szczególne regulacje w zależności od tego, o jakie zamierzenie (zamierzenia) chodzi. I tak w myśl § 2 wspomnianego wyżej art. 67b, w sytuacji, gdy chodzi o zamierzenie wskazane w art. 67b $§ 1$ pkt 3) lit. a) Ordynacji podatkowej (zamierzenia te to naprawienie szkód spowodowanych klęskami żywiołowymi lub innymi nadzwyczajnymi zdarzeniami) ulg w spłacie zobowiązań podatkowych (chodzi o ulgi wskazane w art. 67a Ordynacji podatkowej) można udzielić w formie pomocy indywidualnej albo też w ramach programów pomocowych uregulowanych odrębnymi przepisami.

Z kolei zgodnie z art. 67b $\S 3$ Ordynacji podatkowej w przypadku zamierzeń wskazanych w rzeczonym art. 67b $\S 1$ pkt 3 ) lit. b), c), d), e), f), g), i), j), k), l) (są to następujące zamierzenia: zapobieganie poważnym zakłóceniom w gospodarce o charakterze ponadsektorowym lub likwidacja takich zakłóceń, wspieranie polskich przedsiębiorców prowadzących działalność stanowiącą część przedsięwzięcia gospodarczego, które jest podejmowane w interesie europejskim, promowanie oraz wspieranie zarówno kultury i dziedzictwa narodowego, jak również nauki oraz oświaty, przekazanie rekompensaty za wykonywanie - powierzonych w oparciu o odrębne przepisy - usług, które są świadczone w ogólnym interesie gospodarczym, szkolenie, zatrudnienie, restrukturyzacja, ochrona środowiska, prace badawczo-rozwojowe, regionalna pomoc publiczna) można udzielać ulg w spłacie zobowiązań podatkowych wymienionych w art. 67a Ordynacji podatkowej w postaci pomocy indywidualnej zgodnej z rządowymi lub samorządowymi programami albo można ich udzielać w ramach programów pomocowych, które są określone w odrębnych regulacjach.

Natomiast stosownie do art. 67b § 4 Ordynacji podatkowej, w przypadku zamierzenia wskazanego w art. 67b § 1 pkt 3) lit. h) Ordynacji podatkowej, to znaczy związanego z rozwojem małych i średnich przedsiębiorstw, można udzielać ulg w spłacie zobowiązań podatkowych, o których wspomina art. 67a Ordynacji podatkowej, po dopełnieniu szczegółowych wymogów ustalonych w oparciu o $\S 5$ analizowanego art. 63b. Należy w tym miejscu odwołać się do Rozporzadzenia Rady Ministrów z dnia 31 marca 2009 r. w sprawie udzielania niektórych ulg $w$ spłacie zobowiazań podatkowych stanowiacych pomoc publiczna na rozwój małych i średnich przedsiębiorstw (Dz.U. z 2009 r. nr 59, poz. 488), które zostało wydane właśnie w oparciu o art. 67b § 5 Ordynacji podatkowej, o czym informuje ono we wstępie. Rozporządzenie to (dalej: rozporządzenie RM z dnia 31 marca 2009 r.), zgodnie z jego § 1, ustala dokładne wymogi związane z udzielaniem ,ulg w spłacie zobowiązań podatkowych stanowiących pomoc publiczną na rozwój małych i średnich przedsiębiorstw w zakresie inwestycji, usług doradczych i udziału w targach lub wystawach, do której mają zastosowanie przepisy rozporządzenia Komisji (WE) nr 800/2008 z dnia 6 sierpnia 2008 r. uznającego niektóre rodzaje pomocy za zgodne ze wspólnym rynkiem w zastosowaniu art. 87 i 88 Traktatu (ogólne rozporządzenie w sprawie wyłączeń grupowych) (Dz.Urz. UE L 214 z 09 sierpnia 2008 r., s. 3), [...], 
na podstawie art. 67a i art. 67b $§ 1$ pkt 3 lit. h ustawy z dnia 29 sierpnia 1997 r. - Ordynacja podatkowa, w formie odroczenia terminu płatności podatku" i w pozostałych formach przewidzianych w art. 67a $§ 1$ pkt 1), 2) i 3) Ordynacji podatkowej, włącznie z określeniem sytuacji, gdy udzielanie ulg przyjmuje postać pomocy indywidualnej. Poniżej przedstawiono wybrane rozwiązanie prawne zawarte we wskazanym wyżej rozporządzeniu Rady Ministrów w sprawie udzielania niektórych ulg w spłacie zobowiązań podatkowych stanowiących pomoc publiczną na rozwój małych i średnich przedsiębiorstw.

Do pewnych kategorii pomocy rozporządzenie RM z dnia 31 marca 2009 r. nie znajduje zastosowania (zob. § 3 tego rozporządzenia). Co więcej, nie każdy mały i średni przedsiębior$\mathrm{ca}^{3}$ może skorzystać z pomocy określonej tym rozporządzeniem, o czym stanowi ono w $\S 4$. Otóż w myśl $\S 4$ ust. 1 pkt 1) tego rozporządzenia, mały i średni przedsiębiorca nie może otrzymać takiej pomocy, jeżeli jest on zagrożony. Zgodnie z § 4 ust. 2 pkt 1), 2) i 3) wspomnianego rozporządzenia, mały i średni przedsiębiorca uznawany jest za przedsiębiorcę zagrożonego wówczas, gdy wypełnia poniższe warunki: a) doszło do utraty więcej niż 50\% zarejestrowanego kapitału, z czego więcej niż 25\% utracono w ciągu poprzedzających dwunastu miesięcy (warunek ten dotyczy spółek z ograniczoną odpowiedzialnością), lub b) więcej niż $50 \%$ kapitału zgodnie ze sprawozdaniem finansowym zostało utracone, z czego więcej niż $25 \%$ utracono w ciągu poprzedzających dwunastu miesięcy (warunek ten znajduje zastosowanie do spółki charakteryzującej się tym, że przynajmniej część jej członków odpowiada za jej zobowiązania w sposób nieograniczony), lub c) wypełnia przesłanki warunkujące objęcie spółki postępowaniem upadłościowym (ten warunek odnosi się do każdego rodzaju spółki). Szczególna sytuacja została uregulowana w $\S 4$ ust. 3 rozporządzenia RM z dnia 31 marca 2009 r., który stanowi, że w przypadku, gdy okres, w którym mały i średni przedsiębiorca prowadzi działalność jest krótszy niż trzy lata, wówczas nie może on zostać uznany za zagrożonego przedsiębiorcę, chyba że mały i średni przedsiębiorca wypełnia warunek wymieniony we wspomnianym wyżej punkcie c).

Ponadto, nie można udzielić i wypłacić pomocy przewidzianej w rozporządzeniu RM z dnia 31 marca 2009 r. przedsiębiorcy, który został zobowiązany do zwrotu pomocy na podstawie wcześniejszej decyzji wydanej przez Komisję Europejską, w której uznano niezgodność pomocy z prawem i ze wspólnym rynkiem ( 4 ust. 1 pkt 2) rozporządzenia RM z dnia 31 marca 2009 r.). Natomiast $\S 6$ ust. 1 pkt 1) lit. a) i b), pkt 2) i 3) wspomnianego wyżej rozporządzenia określa przeznaczenie pomocy (chodzi o pomoc wymienioną w $\S 1$ tego rozporządzenia) dla przedsiębiorców wskazując, że można jej udzielić na inwestycje (rozporządzenie precyzuje, iż może to nastąpić w stosunku do kosztów inwestycji, mających związek z jej realizacją, lub w stosunku do kosztów płacy na stanowiskach pracy stworzonych jako bezpośrednia konsekwencja takiej inwestycji), na usługi doradcze, których realizacją zajmują się doradcy zewnętrzni oraz na udział w określonych wydarzeniach (chodzi tutaj o targi lub wystawę). Należy jednak pamiętać, że warunkiem udzielenia wspomnianej wyżej pomocy dla małego i średniego przedsiębiorcy jest to, aby wniosek w sprawie udzielenia ulgi w spłacie zobowiązań podatkowych został przez niego złożony, zanim zostaną rozpoczęte prace nad inwestycją lub inne działania, na które taka pomoc może zostać udzielona ( 6 ust. 2 rozporządzenie RM z dnia 31 marca 2009 r.).

Pojęcie inwestycji zostało zdefiniowane w $§ 5$ pkt 2) rozporządzenia RM z dnia 31 marca 2009 r. Od razu należy nadmienić, iż zgodnie z tym przepisem, jeżeli przedmiotem nabycia są

\footnotetext{
${ }^{3}$ W myśl $§ 5$ pkt 1 rozporządzenia RM z dnia 31 marca 2009 r., występujące w tym rozporządzeniu pojęcie maty $i$ średni przedsiębiorca oznacza „odpowiednio małego i średniego przedsiębiorcę spełniającego warunki określone w załączniku I do rozporządzenia Komisji (WE) nr 800/2008”.
} 
jedynie akcje lub udziały przedsiębiorstwa, to wówczas takiego działania nie można uważać za inwestycję. W rozumieniu tego aktu prawnego, przez pojęcie inwestycja należy rozumieć dwie kategorie działań. Po pierwsze, pojęcie inwestycja należy utożsamiać z inwestycją w rzeczowe aktywa trwałe lub też w wartości niematerialne i prawne powiązane z organizacją nowego przedsiębiorstwa, rozbudowywaniem już istniejącego, różnicowaniem jego produkcji w drodze wprowadzania kolejnych nowych towarów lub też z gruntowną modyfikacją cyklu produkcyjnego w ramach istniejącego przedsiębiorstwa ( $\$ 5$ pkt 2) lit. a) rozporządzeniu RM z dnia 31 marca 2009 r.). Po drugie, zgodnie z $\S 5$ pkt 2) lit. b) omawianego rozporządzenia, inwestycja oznacza nabywanie likwidowanego przedsiębiorstwa lub takiego, które byłoby zlikwidowane w przypadku, gdyby nie nastąpiło jego nabycie, z tym, że chodzi tutaj o sytuację, w której nabywcą przedsiębiorstwa jest inwestor niezależny od zbywcy (wymóg, aby środki były nabyte przez niezależnego inwestora nie znajduje zastosowania w sytuacji, gdy przekazywane przedsiębiorstwo małego przedsiębiorcy otrzymuje rodzina pierwotnego właściciela - ewentualnie pierwotnych właścicieli - lub byli pracownicy).

\section{Udzielanie ulg w przypadkach wyjątkowych}

Wracając do regulacji zawartych w Ordynacji podatkowej, trzeba wspomnieć, że w myśl jej art. 67d § 1 pkt 1), 2), 3) i 4), istnieje - w pewnych okolicznościach - możliwość udzielenia $\mathrm{z}$ urzędu przez organ podatkowy ulg w spłacie zobowiązań podatkowych wymienionych w art. 67a $\S 1$ pkt 3) Ordynacji podatkowej (chodzi tutaj o zastosowanie ulgi polegającej na umorzeniu - w całości lub w części - zaległości podatkowych, odsetek za zwłokę lub opłaty prolongacyjnej). Te okoliczności, zgodnie z rzeczonym art. 67d § 1 pkt 1), 2), 3) i 4), polegają na tym, że: a) istnieje przypuszczenie (ma być ono uzasadnione), iż postępowanie egzekucyjne nie przyniesie kwoty przekraczającej wielkość wydatków egzekucyjnych, b) wielkość zaległości podatkowej jest co najwyżej równa pięciokrotności kosztów upomnienia w ramach postępowania egzekucyjnego, c) nie doszło do zaspokojenia zaległości podatkowej w ukończonym postępowaniu likwidacyjnym lub upadłościowym, d) doszło do śmierci podatnika, po którym nie został żaden majątek lub zostały ruchomości, z których nie prowadzi się egzekucji w oparciu o odrębne przepisy albo pozostały przedmioty codziennego użytku domowego o łącznej wartości co najwyżej równej pięciu tysiącom złotych, i równocześnie nie ma spadkobierców (chodzi tutaj o innych spadkobierców niż Skarb Państwa lub jednostka samorządu terytorialnego) i nie można orzec wobec osoby trzeciej o jej odpowiedzialności podatkowej. Jeżeli doszło do sytuacji wymienionych w punktach c) i d), wówczas decyzję, którą umorzono zaległość podatkową, należy pozostawić w aktach sprawy (art. 67d § 2 Ordynacji podatkowej), przy czym regulacja ta, jak i unormowania wskazane we wspomnianych wyżej punktach c) i d), znajdują odpowiednie zastosowanie do umarzania zaległości tak płatnika, jak i inkasenta (art. 67d § 3 Ordynacji podatkowej).

Kończąc prezentację unormowań przyjętych w Ordynacji podatkowej, należy jeszcze wspomnieć o art. 22 tej ustawy, w którym to przepisie znalazły się rozwiązania prawne będące ulgami uznaniowymi (Etel, 2009: 232, 235, 371; zob. też: Gruszczyński, 2011: 211). W myś1 art. $22 \S 2$ pkt 1) i pkt 2) Ordynacji podatkowej, płatnik może zostać zwolniony przez organ podatkowy (działający na wniosek podatnika) z obowiązku pobrania podatku w sytuacji, gdyby taki pobór stanowił zagrożenie dla ważnych interesów podatnika, a zwłaszcza jego egzystencji, lub w sytuacji, gdy zostanie przez podatnika uprawdopodobnione, iż kwota pobranego podatku byłaby niewspółmiernie wysoka w porównaniu do kwoty podatku należnego za rok podatkowy lub za inny okres rozliczeniowy.

Ponadto, zgodnie z art. $22 \S 1$ pkt 1) i pkt 2) Ordynacji podatkowej, ministrowi właściwemu do spraw finansów publicznych przysługuje uprawnienie (jest ono realizowane przez wydanie odpowiedniego rozporządzenia): a) do zaniechania (w całości lub w części) poboru podatków 
(ustawa wymaga określenia rodzaju podatku, okresu, którego dotyczy zaniechanie, oraz kręgu podatników, do których zaniechanie ma zastosowanie), b) do zwolnienia pewnych grup płatników z obowiązku poboru podatków lub zaliczek na podatki (w tym zakresie wymagane jest określenie terminu wpłaty podatku i wynikających z takiego zwolnienia obowiązków informacyjnych leżących po stronie podatników, chyba że na podatniku spoczywa obowiązek przeprowadzenia rozliczenia takiego podatku w okresie rocznym lub w innym okresie rozliczeniowym), przy czym uprawnienia te, wskazane w punktach a) i b), mogą być realizowane, o ile jest to uzasadnione interesem publicznym lub ważnym interesem podatników (zob. też inne regulacje dotyczące działań organu podatkowego, zawarte w $\S 2 \mathrm{a}, \S 5$ i § 6 artykułu 22 Ordynacji podatkowej). Jednocześnie, w odniesieniu do rozporządzenia wskazanego w wyżej wymienionym punkcie a), ustawodawca zamieścił w art. 22 1a Ordynacji podatkowej następujące zastrzeżenie: ,Rozporządzenie [...], dotyczące zaniechania poboru podatku od podatników prowadzących działalność gospodarczą, którzy w wyniku zaniechania poboru podatku staną się beneficjentami pomocy w rozumieniu przepisów o postępowaniu w sprawach dotyczących pomocy publicznej, stanowiące pomoc publiczną, zawiera program pomocowy, określający przeznaczenie i warunki dopuszczalności pomocy publicznej”.

\section{Zakończenie}

W czasie dekoniunktury rynkowej podmioty gospodarcze szczególnie chętnie i w szerokim zakresie korzystają z różnego rodzaju ulg podatkowych wprowadzonych przez ustawodawcę. W niniejszym opracowaniu skoncentrowano się zwłaszcza na rozwiązaniach prawnych wynikających z Ordynacji podatkowej. W ramach tej ustawy omówiono przede wszystkim regulacje prawne zawarte $\mathrm{w}$ rozdziale 7 a pod tytułem Ulgi w spłacie zobowiazań podatkowych (rozdział ten stanowi fragment działu III Ordynacji podatkowej). Nie można jednak zapominać, że pewne istotne regulacje prawne dotyczące prezentowanej problematyki zostały przez polskiego ustawodawcę zamieszczone również w innych aktach prawnych. Wybrane unormowania zamieszczone w tych aktach również zostały uwzględnione w niniejszym opracowaniu.

\section{Akty prawne}

Ustawa z dnia 26 lipca 1991 r. o podatku dochodowym od osób fizycznych (tekst jednolity: Dz.U. z dnia 3 kwietnia 2012 r., poz. 361 z późniejszymi zmianami).

Ustawa z dnia 15 lutego 1992 r. o podatku dochodowym od osób prawnych (tekst jednolity: Dz.U. z 2011 r. nr 74, poz. 397 z późniejszymi zmianami).

Ustawa z dnia 20 października 1994 r. o specjalnych strefach ekonomicznych (tekst jednolity: Dz.U. z 2007 r. nr 42, poz. 274 z późniejszymi zmianami).

Ustawa z dnia 29 sierpnia 1997 r. Ordynacja podatkowa (tekst jednolity: Dz.U. z dnia 3 lipca 2012 r., poz. 749 z późniejszymi zmianami).

Ustawa z dnia 2 lipca 2004 r. o swobodzie działalności gospodarczej (tekst jednolity: Dz.U. z 2010 r. nr 220, poz. 1447 z późniejszymi zmianami).

Ustawa z dnia 30 kwietnia 2010 r. o zasadach finansowania nauki (Dz.U. z 2010 r. nr 96, poz. $615 \mathrm{z}$ późniejszymi zmianami).

Rozporządzenie Ministra Finansów z dnia 22 sierpnia 2005 r. w sprawie właściwości organów podatkowych (Dz.U. z 2005 r. nr 165, poz. 1371 z późniejszymi zmianami).

Rozporządzenie Rady Ministrów z dnia 31 marca 2009 r. w sprawie udzielania niektórych ulg w spłacie zobowiazań podatkowych stanowiacych pomoc publiczna na rozwój matych i średnich przedsiębiorstw (Dz.U. z 2009 r. nr 59, poz. 488). 


\section{Literatura}

Brzeziński, B. (2008). Wprowadzenie do prawa podatkowego. Toruń: Towarzystwo Naukowe Organizacji i Kierownictwa „,Dom Organizatora”.

Ciborowski, R. (2005). Uwarunkowania konwergencji technologicznej Polski. W: Z. Dach, A. Pollok (red.), Gospodarka Polski po 15 latach transformacji. Kraków: Polskie Towarzystwo Ekonomiczne, 303-322.

Dauter, B. (2011). W: S. Babiarz, B. Dauter, B. Gruszczyński, R. Hauser, A. Kabat, M. Niezgódka-Medek, Ordynacja podatkowa. Komentarz. Warszawa: Wydawnictwo LexisNexis Polska Sp. z o.o.

Etel, L. (2009). W: C. Kosikowski, L. Etel, R. Dowgier, P. Pietrasz, M. Popławski, S. Presnarowicz, Ordynacja podatkowa. Komentarz. Warszawa - Kraków: LEX a Wolters Kluwer business.

Frąckowiak, J. K. (1999). Polityka wspierania innowacyjności w Polsce - nowe założenia, wymiar regionalny. W: B. Marciniec, J. Guliński (red.), Parki naukowe i technologiczne. Polska perspektywa. Science and technology parks. The Polish perspective. Materiaty prezentowane na międzynarodowej konferencji. Poznań, 19-21 marca 1998. Poznań: Wydawnictwo Poznańskie, 11-14.

Gruszczyński, B. (2011). W: S. Babiarz, B. Dauter, B. Gruszczyński, R. Hauser, A. Kabat, M. Niezgódka-Medek, Ordynacja podatkowa. Komentarz. Warszawa: Wydawnictwo LexisNexis Polska Sp. z o.o.

Mastalski, R. (2011). Prawo podatkowe. Warszawa: Wydawnictwo C.H. Beck.

Nykiel, W. (2002). Cele i funkcje ulg i zwolnień podatkowych. W: praca zbiorowa, Regulacje prawno-podatkowe i rozwiazania finansowe. Pro publico bono. Księga jubileuszowa Profesora Jana Gtuchowskiego. Toruń: Towarzystwo Naukowe Organizacji i Kierownictwa „Dom Organizatora”, 189-195.

Wisła, R. (2004). Możliwości zarządzania ryzykiem fiskalnym przedsiębiorstwa. W: S. Owsiak (red.), Polityka fiskalna państwa i jej wptyw na finanse przedsiębiorstw. Bielsko-Biała: Wydawnictwo Wyższej Szkoły Bankowości i Finansów w Bielsku-Białej, 188-196.

Paweł Marek Woroniecki, dr nauk prawnych, Uniwersytet Jagielloński, Katedra Polityki Gospodarczej, Wydział Prawa i Administracji.

Ukończył studia prawnicze na Wydziale Prawa i Administracji Uniwersytetu Jagiellońskiego w Krakowie. Po odbyciu studiów doktoranckich na tym samym wydziale uzyskał stopień naukowy doktora nauk prawnych. Obecnie pracuje na stanowisku asystenta w Katedrze Polityki Gospodarczej na Wydziale Prawa i Administracji Uniwersytetu Jagiellońskiego. Jego zainteresowania badawcze dotyczą funkcjonowania systemu finansów publicznych oraz działalności podmiotów gospodarczych.

Pawel Marek Woroniecki, PhD in Law, Jagiellonian University in Cracow, Faculty of Law and Administration, Chair of Economic Policy.

Paweł Marek Woroniecki graduated in Legal Studies at the Faculty of Law and Administration of the Jagiellonian University in Cracow. Obtained a PhD in Law, after completing doctoral studies at the same faculty. Presently employed in the position of assistant at the Chair of Economic Policy of the Faculty of Law and Administration of the Jagiellonian University. Research interests of the author include: functioning of the public finance system, and activities of economic agents.

Adres/Address:

Uniwersytet Jagielloński w Krakowie, Wydział Prawa i Administracji

Katedra Polityki Gospodarczej

ul. Bracka 12, 31-005 Kraków, Polska

e-mail: pawel.woroniecki@uj.edu.pl 